\title{
Pilkada yang Membelah Media (Relasi Kuasa di Balik Kontestasi Wacana Pilgub Sulsel 2018)
}

\author{
Choice of the Head of the Region Which Made Mediac (Relation of Power in the Wacana \\ Contestation Behind 2018) \\ Rahma Amin 1, Sawedi Muhammad ${ }^{2}$, Rahmat Muhammad ${ }^{3 *}$ \\ ${ }^{1}$ Wartawan Harian Berita Radar, Makassar, Indonesia, email: rahmaamin17@gmail.com \\ ${ }^{2}$ Dosen Sosiologi Fisip Universitas Hasanuddin, Makassar, Indonesia, email: msawedi@yahoo.com \\ ${ }^{3}$ Dosen Sosiologi Fisip Universitas Hasanuddin, Makassar, Indonesia, email: rahmatmuhammad131@gmail.com
}

\section{A R T I C L E I N F O}

\section{How to Cite:}

Amin, R., Muhammad, S., \& Muhammad, R. (2019).

Pilkada yang Membelah Media (Relasi Kuasa di Balik Kontestasi Wacana Pilgub Sulsel 2018). Hasanuddin Journal of Sociology (HJS), 1(1), 43-55.

Keywords:

Media, Power, Discourse, and South Sulawesi Election

\section{Kata Kunci :}

Media, Kekuasaan, Wacana, dan Pilgub Sulsel

\begin{abstract}
A B S T RA C T
The election of governor of South Sulawesi (Pilgub Sulsel) held simultaneously on 27 June together with election of 11 regency / city elections, succeeded in making two media namely daily Radar Makassar and People of South Sulawesi become split in packing news related four candidate pairs to fulfill the interest political economy. This study aims to examine the media discourse in relation to the power and interests that surround it in the context of political practice in South Sulawesi Governor Election, and the dynamics of what happens in the politic of redactur and the power relations created through text to be formed into political news. This research uses qualitative method with critical paradigm as its methodology, and primary and secondary data obtained by conducting indepth interviews of journalists involved in the production of news, including editors and media leaders who became the object of this research. The results showed that both media make contestation discourse as a control or self-censorship mechanism for their reporting. In this study, the political economy behind the practice of self-censorship is enriched with the power play dimension among individual journalists and self-help practices that have become the daily habitat of Radar Makassar and the People of South Sulawesi. The practice of self-censorship is done in order to serve the interests of capital and the interests of the "little kings" who ruled in the ranks of the editor.
\end{abstract}

\footnotetext{
A B S T R A K

Pemilihan gubernur Sulawesi Selatan (Pilgub Sulsel) yang digelar serentak pada 27 Juni bersama dengan 11 pemilihan kepala daerah (Pilkada) kabupaten/kota, berhasil membuat dua media yakni harian Radar Makassar dan Rakyat Sulsel menjadi terbelah dalam mengemas berita terkait empat pasangan calon guna memenuhi kepentingan ekonomi politik tertentu
} 
.Penelitian ini bertujuan untuk mengkaji wacana media dalam hubungannya dengan kekuasaan dan kepentingan yang mengitarinya dalam konteks praktik politik di Pemilihan Gubernur (Pilgub)Sulsel, dan dinamika apa yang terjadi di dalam ruang redaksi (politic of redactur) serta relasi kuasa yang tercipta lewat teks yang akan dibentuk menjadi berita politik. Penelitian ini menggunakan metode kualitatif dengan paradigma kritis sebagai metodologinya, dan data primer dan sekunder yang diperoleh dengan melakukan wawancara mendalam terhadap wartawan yang terlibat dalam produksi pemberitaan, termasuk redaktur dan pimpinan media yang menjadi objek penelitian ini.Hasil penelitian menunjukkan kedua media ini menjadikan kontestasi wacana sebagai mekanisme kontrol atau swasentor atas pemberitaan mereka. Dalam penelitian ini, kuasa ekonomi politik di balik praktik swasensor ini diperkaya dengan dimensi permainan kuasa di antara individu wartawan dan praktik swasensor yang telah menjadi habitus harian Radar Makassar dan Rakyat Sulsel. Praktik swasensor itu dilakukan demi melayani kepentingan kapital dan kepentingan "raja-raja kecil" yang berkuasa di jajaran redaksi.

(C) 2019 Hasanuddin Journal of Sociology. All rights reserved.

\section{PENDAHULUAN}

Kehadiran media bukanlah suatu ruang vakum, media bisa menjadi wahana untuk mendominasi, menguasai, mengarahkan pikiran publik, merekonstruksikan realitas dan menanamkan ideologi tertentu. Media menjadi alat untuk melegitimasi eksistensi dan struktur kekuasaan politik dan ekonomi. Tetapi sebaliknya media pun bisa menjadi alat untuk mendelegitimasi kekuasaan, membongkar kemandekan politik dan menjatuhkan kekuasaan yang otoriter. Dalam kurung waktu 15 tahun terakhir, bangsa Indonesia merayakan kebebasan bermedia, kecenderungan media sebagai alat kapital memudahkan orang yang memiliki modal untuk menaruh kepentingannya di atas media, baik kepentingan ideologi (dalam arti luas), modal, partai politik maupun komunitas. (Sudibyo,2013).

Padahal media massa sebagai lembaga yang netral, bersifat mandiri(independent) sedapat mungkin melakukan fungsinya menyajikan informasi dengan tidak berpihak dan tergantung pada kelompok tententu di masyarakat, termasuk di dalamnya para elit-elit politik. Sebab hanya dengan melepaskan diri dari segala campur tangan kepentingan, media baru akan mampu memberikan ruang aspirasi untuk segala kebutuhan informasi bagi masyarakat. Olehnya media sebagai insan dan lembaga pers berkewajiban mencari, penulis, dan menyajikan fakta-fakta dari sebuah peristiwa kepada khalayak, tanpa mereduksi dan menambah informasinya. Kinerja wartawan agar tetap profesional dan ideal dalam menjalankan tugasnya, sebenarnya telah di atur dalam Undang Undang Nomor 40 Tahun 1999 Pasal 7 Ayat 2 tentang Pers.(Kusumaningrat dan Purnama, 2012).

Pada Pasal 1 UU Pers secara terang menyebutkan wartawan Indonesia bersikap independen, yang 
dimaksud independen adalah memberitakan peristiwa atau fakta sesuai dengan suara hati nurani tanpa campur tangan,paksaan, dan intervensi dari pihak lain termasuk perusahaan pers. Sedang akurat berarti dipercaya benar sesuai keadaan objektif ketika peristiwa terjadi, sementara berimbang diartikan kalau semua pihak mendapat kesempatan setara dan tidak beritikad buruk berarti tidak ada niat secara sengaja dan semata-mata untuk menimbulkan kerugian pihak lain.(UU Pers).

Melalui kekuatan yang sangat besar, yakni dapat membuat institusi lain menjadi lebih kuat. Melalui kemampuannya dalam mengemas berita dan menyebarkan pesan ke banyak orang secara serentak di berbagai tempat sekaligus, media justru menjadi alat propaganda untuk memenuhi kepentingan ekonomi politik tertentu, akibatnya roh media yang harusnya independen menjadi hilang. Hal ini sering terjadi dalam momen Pilkada, di mana media dianggap sebagai sarana yang paling efektif untuk menyampaikan pesan-pesan politik para pemilik kepentingan. Tidak sedikit para elit politik yang memesan kolom-kolom terntentu pada media yang untuk memasang foto-foto kegiatan para kandidat menjelang pemilihan kepala daerah.

Era pasca reformasi seperti sekarang ini media tidak lagi sekadar menjadi mesin ideologi informasi yang memiliki spektrum tanggung jawab sosial dan partisipasi politis dalam mengkritisi kebijakankebijakan pengusaha, lebih dari itu media telah menjadi lembaga bisnis pencetak uang dan modal. Tidak sedikit kasus kepentingan bisnis menjadi berita yang terdepan untuk dimuat, sehingga menarik untuk ditelaah. Gerakan reformasi berhasil mendorong setidaknya dua perubahan yang signifikan Pertama, era kebebasan pers yang menggantikan tirania utoritatif Kedua, perubahan mendasar dari reformasi adalah agenda otonomi daerah yang mengusung asas desentralisasi. (Istanto:2016).

Media lokal dapat memainkan berbagai macam peran yang di sesuaikan dengan tujuan pokok diberlakukannya desentralisasi itu. Salah satu kasus menarik yang terjadi pada media lokal di Sulsel adalah saat perhelatan pesta demokrasi lima tahunan yakni pemilihan gubernur dan wakil gubernur Sulsel yang digelar 27 Juni 2018. Terjadi pembelahan pemberitaan politik yang terbit di harian Radar Makassar dan Rakyat Sulsel dalam menginformasikan sejumlah kandidat atau figur bakal calon yang digadang-gadang maju pada pertarungan merebut kursi orang nomor satu di Sulsel, hingga kemudian di tetapkan secara resmi sebagai pasangan calon (Paslon) oleh KPU Sulsel.

Tujua dari penelitian ini yakni untuk memahami dan menafsirkan bagaimana para aktor sosial di ruang redaksi Radar Makassar dalam memproduksi teks, apa kepentingan, dan motifnya. Begitu juga dengan pemberitaan seputar isu Pilgub Sulsel yang dimuat di harian Rakyat Sulsel. Penulis ingin pula membongkar struktur ekonomi politik yang mempengaruhi praktik sensor-diri yang telah menjadi budaya organisasi, bagaimana upaya sebagian wartawannya menyiasati budaya organisasi ini sehingga menciptakan keterbelahan pemberitaan di kedua media ini. 


\section{KAJIAN PUSTAKA}

\subsection{Kekuasaan di Balik Praktik Wacana Media}

Media massa merupakan alat atau mediator yang efektif dalam publikasi ideology baik ideologi pro maupun kontra terhadap suatu diskursus. Menurut Eriyanto (2005:13) bahwa teks merupakan salah satu bentuk praktek ideologi, bahasa, tulisan, pilihan kata maupun struktur gramatika dipahami sebagai pilihan yang diungkapkan membawa makna ideologi tertentu dalam taraf memenangkan dukungan publik, termasuk wacana- wacana politik terkait kontestasi Pilgub Sulsel dikonstruksi oleh media massa. Studi wacana dalam politik sangat dipengaruhi oleh pendekatan post strukturalis, yang memandang kemunculan realitas sosial bukan karena keinginan sejarah, melainkan karena kepentingan dari kekuasaan.

Dalam pendekatan ini, kekuasaan dipahami sebagai sesuatu yang bersifat tidak produktif, yakni bekerja dengan cara menindas. Sebaliknya, kekuasaan dipandang sebagai sesuatu yang bersifat produktif yang dapat mengkonstruksi dunia sosial melalui cara-cara tertentu.(Jorgensen dan Louse, 2007).Dalam memproduksi kekuasaan, pendekatan post strukturalis menempatkan peran penting wacana dalam proses pembentukan realitas sosial. Tanpa adanya produksi, akumulasi, sirkulasi dan pemfungsian wacana, kekuasaan tidak dapat dengan sendirinya dibangun, dikonsolidasikan maupun diimplementasikan. Pengetahuan yang hadir dalam wacana tidak dapat dikatakan sebagai pengetahuan yang obyektif. Pengetahuan memberikan klaim kebenaran bagi agen kekuasaan melalui penciptaan ukuran kriteria-kriteria dan prosedur-prosedur. Dengan klaim kebenaran ini, kekuasaan akan dapat mengontrol penerima wacana yang disebarkannya.

Dengan demikian pendekatan wacana, yang digunakan penulis dalam penelitian ini adalah memahami wacana bukanlah sebagai medium netral di luar subyek penyebar wacana. Pemegang kekuasaan memproduksi wacana di bawah kondisi dan kepentingan tertentu untuk meraih kontrol. Bahasa sebagai alat wacana dianggap sebagai representasi yang berperan pula dalam membentuk jenis-jenis subyek tertentu, tema-tema wacana tertentu maupun strategi-strategi di dalamnya.Bahasa dalam suatu wacana menjadi representasi, karena wacana tersusun dalam sebuah tatanan bahasa yang masuk akal. Tatanan ini disebut dengan structure discoursif.(Sobur,2009). Struktur inilah yang membentuk cara seseorang mempersepsikan suatu obyek. Struktur diskursif yang berbeda dapat membuat sebuah obyek yang sama, dipersepsikan secara berbeda. Perbedaan cara pandang ini dapat melahirkan pemahaman yang berbeda dan akan melahirkan aksi yang berbeda pula.

Dengan menempatkan wacana sebagai praktik kekuasaan, kita memahami kekuasaan tidak hanya bekerja dalam negara (statecentric). Kekuasaan justru hadir pada setiap hubungan sosial yang ada. 
Dalam relasi-relasi sosial tersebut terdapat rangkaian jaringan kekuasaan, relasi kekuasaan yang jamak, yang mengontrol tubuh, seksualitas, keluarga, hubungan kekerabatan, pengetahuan teknologi dan seterusnya.(Ritzer.2007). Kemampuan wacana membangun klaim kebenaran membuat wacana mampu melestarikan ataupun mengubah hubungan-hubungan kekuasaan yang ada di dalam masyarakat. Pengkonstruksian dunia sosial tidak hanya disusun oleh satu wacana, tetapi oleh banyak wacana. Meskipun demikian akan selalu ada wacana dominan yang berperan besar mengkonstruksi realitas. Pola hubungan yang terbangun akibat dominasi wacana itu dapat disebut dengan hubungan hegemonik.(Eni.2010) Dalam pola hubungan hegemonik, kelompok yang berkuasa memproduksi wacana yang dapat membuat seseorang, komunitas, masyarakat ataupun sebuah kelas sosial dapat dikontrol. Kemampuan ini muncul karena wacana yang diproduksi mampu menginternalisasi, sehingga menjadi sebuah konsensus kebenaran yang harus dijalankan.

Meskipun ada wacana dominan yang mampu menghegemoni, namun penulis tidak sepakat dengan cara pandang hegemoni akan bersifat statis. Hal ini karena tatanan sosial tidak dibangun hanya oleh satu wacana melainkan beragam. Karena manusia mempunyai kapasitas untuk merefleksikan dan membandingkan wacana. Hal inilah yang mengakibatkan masing-masing wacana akan saling berinteraksi.Dengan demikian, hegemoni tidak hanya sebuah proses dominasi, tetapi juga proses negosiasi yang melahirkan konsensus tentang makna. Dalam negosiasi tersebut, masing-masing wacana dapat saling meniadakan, namun juga dapat saling mendukung.

Unsur-unsur yang menentang wacana dominan akan membekali pengikutnya dengan sumber daya untuk melakukan perlawanan. Akibatnya, hegemoni tidak akan pernah berlangsung stabil, namun senantiasa berubah dan tidak pernah selesai. Konsensus yang dibangun selalu berkaitan dengan masalah derajat keseimbangan hubungan antar wacana yang tidak stabil. Wacana dominan akan berdampak serius. Pertama, wacana dominan memberikan arahan bagaimana suatu obyek harus dibaca dan dipahami karena wacana tersebut memberikan pilihan yang tersedia dan siap pakai. Pandangan yang lebih luas menjadi terhalang karena dibatasi oleh batas-batas diskursif tersebut. Kedua, batas-batas yang diciptakan oleh struktur diskursif bukan hanya membatasi pandangan kita, tetapi juga menyingkirkan wacana lain yang tidak dominan.(Hamad,2004).

Dengan demikian, penulis menempatkan perhatian terhadap wacana sebagai bagian utama dalam analisis politik. Dalam pendekatan ini, wacana dipandang sebagai sebuah bentuk praktik sosial yang berada dalam hubungan dialektis dengan realitas sosial yang lain. Wacana dapat mengkonstruksi dunia sosial, namun produksi wacana juga dipengaruhi oleh dunia sosial misalnya pergolakan politik yang semakin dinamis di Pilgub Sulsel akan berimplikasi pada kualitas pendewasaan demokrasi yang termanifestasi lewat proses pilkada.Wacana sendiri adalah istilah yang dipakai oleh berbagai disiplin 
ilmu, mulai dari politik, sosiologi, linguistic, psikologi, komunikasi dan sebagainya. Setiap disiplin ilmu tersebut terkadang berbeda dalam konsepsi dan pendekatan yang dipakai. Definisi mengenai wacana dalam Eryanto (2005:2) antara lain:

a. Collin Concise English Dictionary, 1999.

Wacana adalah (1) komunikasi verbal, ucapan, percakapan; (2) sebuah perlakuan formal dari subjek dalam ucapan atau tulisan; (3) sebuah unit teks yang digunakan oleh linguis untuk menganalisis satuan lebih dari kalimat.

b. Roger Fowler, 1977.

Wacana adalah komunikasi lisan atau tulisan yang dilihat dari titik pandang kepercayaan, nilai, dan kategori yang masuk di dalamnya, kepercayaan di sini mewakili pandangan dunia, sebuah organisasi atau representasi dari pengalaman.

c. Foucault, 1972. Wacana kadangkala sebagai bidang dari semua pernyataan (statement), kadangkala sebagai sebuah individualisasi kelompok pernyataan dan kadangkala sebagai praktik regulative yang dilihat dari sejumlah pernyataan.

Dalam analisis wacana pendekatan Foucault, kuasa tidak dimaknai dalam term "kepemilikan", di mana seseorang mempunyai sumber kekuasaan tertentu. Kuasa menurut Foucault tidak dimiliki tetapi dipraktikkan dalam suatu ruang lingkup di mana ada banyak posisi yang secara strategis berkaitan satu sama lain. Bagi Foucault, kekuasaan selalu terakulasikan lewat pengetahuan, dan pengetahuan selalu mempunyai efek kuasa. Penyelenggara kekuasaan menurut Foucault, selalu memproduksi pengetahuan sebagai basis kekuasaannya. Pengetahuan tidak merupakan pengungkapan samar-samar dari relasi kuasa, tetapi pengetahuan berada di dalam relasi-relasi kuasa itu sendiri. Tidak ada pengetahuan tanpa kuasa, dan sebaliknya tidak ada kuasa tanpa pengetahuan(Halwati.2013).

"Untuk mengetahui relasi kuasa/pengetahuan dikonstruksi, dapat dilakukan analisis wacana menurut Faucault yang meliputi analisis arkeologi pengetahuan yang memungkinkan penyelidikan peristiwa- peristiwa wacana, pernyataan yang dibincangkan dan dituliskan. Faucult melengkapi perangkat analisis dengan genealogi kuasa untuk mengungkap keterkaitan antara pengetahuan dan kuasa. Analisis wacana mengacu pada pemikiran Michel Foucault meliputi metode analisis genealogi kuasa dan analisis arkeologi pengetahuan. Dalam analisis genealogi kuasa, tugas geneolog adalah memeriksa rangkaian wacana terbentuk; analisis hubungan kesejarahan antara kuasa dengan wacana"(Foucault, 1994:387 dalam Halwati. 2013).

Roses genealogi adalah memeriksa serangkaian wacana terbentuk, analisis hubungan kesejarahan antara kuasa dengan wacana dan bukan menyelidiki suatu konspirasi melalui kesadaran aktor-aktornya 
(Ritzer, 2003: 78-80).Suatu teks di media massa dapat dilihat adanya keterjalinan antar teks dengan teks sebelumnya. Teks berfungsi dalam kaitannya dengan situasi awalnya. Teks-teks yang terlibat di media massa meninggalkan jejak-jejak di belakang yang menentukan kaitannya dengan teks sebelumnya. Arkeologi pengetahuan memungkinkan penyelidikan peristiwa- peristiwa wacana, pernyataanpernyataan yang dibincangkan dan dituliskan. Langkah ini dilakukan untuk mengetahui analisis kearsipan suatu teks. Menurut Foucault, objek kajian penelitian ini terletak pada arsip (dokumen), yang merupakan akumulasi dari keberadaan wacana. Arkeologi adalah analisis wacana dalam bentuk kearsipannya. Arkeologi menggambarkan wacana- wacana sebagai praksis-praksis yang dikhususkan dalam elemen sebuah arsip.(Halwati.2013)

Berbicara kekuatan media dan komunikasi, pendekatan Manuel Castells mengundang banyak perhatian besar belakangan ini. Dalam bukunya yang berjudul Comunication Power, Castells mendefinisikan kekuasaan komunikasi sebagai bentuk kekuatan jaringan.(Fuchs.2015:13) :

"The relational capacity that enables a social actor to influence asymmetrically the decisions of other social actor(s) in ways that favor the empowered actor's will, interests, and values". Power is associated with coercion, domination, violence or potential violence, and asymmetry."

Sementara Giddens dalam tori struktutrrasi melihat kekuasaan tidak selalu memaksa, keras dan asimetris didistribusikan. Oleh karena itu menjadi mungkin untuk memahami dan menganalisis situasi dan sistem sosial di mana kekuasaan lebih simetris didistribusikan. Misalnya situasi dan sistem demokrasi partisipasif. Keakuasaan sebagai kapasitas transformatif tampaknya memang menjadi aspek fundamental dari semua masyarakat. Ini juga berarti bahwa ada perbedaan besar antara pendekatan Giddens dan Castells dalam teori strukturasi.Gagasan Castells tentang kekuasaan adalah bahwa ia melihat koersif, kekerasan, hubungan kekuasaan dominatif sebagai hubungan dasar masyarakat sepanjang sejarah, geografi dan budaya. Selanjutnya, Castells menolak "gambar naif dari manusia didamaika masyarakat, utopia normatif yang mendustakan dengan observasi sejarah.

\subsection{Politik Media}

Perubahan orientasi politik suatu negara akan berpengaruh langsung terhadap sistem media massa yang dipilih dengan menempatkan media sebagai indikator keberhasilan dan kesungguhan pemerintah dalam menjalankan agenda reformasi. Konsepsi politik media dipahami sebagai upaya untuk mewujudkan kebebasan media, kebebasan informasi dan penyampaian ide dan pemikiran. Hal ini juga sering dipahami sebagai kajian kepentingan politik oleh aktor-aktor politik yang terkait dengan media.Politik dari media itu sendiri dikaitkan dengan arah dan kebijakan yang nantinya akan dikeluarkan oleh media. Sebab setiap media mempunyai hak dan wewenang dalam memuat atau mengeluarkan suatu peristiwa atau informasi yang dibutuhkan oleh publik. Dan dalam wacana 
akademis konsep politik media ini dapat dipahami setidaknya dalam tiga frame analisis (Hermin :2007) yakni politik media sebagai kebijakan negara, politik media sebagai sistem jaringan perilaku antar aktor dan politik media sebagai konvergensi ekonomi-politik.

Politik media sebagai sistem jaringan perilaku antar aktor, dalam konsep ini politik media terkait erat dengan media massa sebagai arena yang di dalamnya bertemu berbagai kepentingan aktor baik ekonomi dan politik. Menyebut beberapa di antaranya penyelenggara media penyiaran, percetakan, aktor dari sistem intermediary (yang terdiri dari kelompok agama, perserikatan, dan asosiasi-asosiasi dalam masyarakat). Aktor-aktor yang relevan dari jaringan kerja yang sama akan berusaha sekuat tenaga dengan berbagai cara untuk mempengaruhi khalayak untuk menggolkan wacana utama yang mampu mewakili berbagai kepentingan mereka.Secara umum, politik media dalam konteks ini dipahami sebagai jaringan hubungan antara aktor politik ataupun ekonomi, yang berkepentingan terhadap proses pengembangan wacana dalam sebuah tema tertentu. Artinya masing-masing aktor akan saling terkait dalam sebuah korporasi tindakan yang relevan satu dengan yang lainnya.

\section{METODOLOGI PENELITIAN}

Studi ini menggunakan metode kualitatif dengan paradigma kritis sebagai metodologinya. Fokusnya diarahkan untuk mengetahui bagaimana cara aktor-aktor politik tersebut menanamkan kepentingannya kepada media sehingga mempengaruhi produksi berita , dinamika apa yang terjadi dalam ruang redaksi terkait produksi berita antara wartawan dan redaksi serta pola hubungan kekuasaan yang tercipta di dalamnya. Pendekatan ini dianggap dapat menjelaskan relasi kuasa di balik kontestasi pemberitaan harian Radar Makassar dan harian Rakyat Sulsel tentang pertarungan wacana pada Pilgub Sulsel,dengan mempertimbangkan faktor internal dan eksternal kedua media tersebut. Pendekatan kualitatif juga mampu menjelaskan kenapa kontestasi ini terjadi dan faktor politik-ekonomi-budaya yang melatarinya. Sebagaimana yang dijelaskan oleh Denzin dan Lincoln dalam Agus Salim(2006),dimana penelitian kulitatif berupaya memahami dan memberi tafsiran pada fenomena yang dilihat dari makna yang diberikan orang-orang kepada fenomena tersebut.

Perspektif paradigma ini juga menekankan sifat holistik atau komprehensif, sehingga pada umumnya merupakan suatu multi level analisis atau tidak terbatas pada satu jenjang analisis saja. Misalnya, bila kita melakukan analisis teks isi media, maka akan disebut tidak holistik jika tidak memperhatikan konteks struktur dan budaya di mana teks ini diproduksi dan juga dikonsumsi. Dalam hal ini, kriteria hasil penelitiannya adalah sejauh mana penelitian tersebut memperlihatkan konteks sejarah, sosial, budaya, ekonomi,dan politik dan teks berita. Teknik pengumpulan data melalui 
observasi, studi pustaka, dan wawancara.

\section{HASIL DAN PEMBAHASAN}

\subsection{Kuasa Aktor di Balik Berita}

Media massa sebagai sarana komunikasi dan informasi memberi peran penting dalam pembentukan opini publik. Dalam kaitannya dengan pemberitaan seputar empat paslon di Pilgub Sulsel yang ditulis awak media Radar Makassar maupun Rakyat Sulsel banyak ditemukan berita-berita yang bias memandang sebuah kasus atau isu tertentu. Sehingga terkesan adanya pretensi yang bersifat konspiratif (hidden agenda) baik yang bersifat politik maupun interest (kepentingan).Sebagaimana disinggung oleh Alex Sobur (2006) bahwa media massa sesungguhnya berada di tengah realitas sosial yang sarat dengan berbagai kepentingan, konflik, dan fakta yang kompleks dan beragam. Tidak hanya itu media melalui awak jurnalis secara intens kerap menciptakan suatu realitas yang dimiliki dan dialaminya secara subyektif. Subyektivitas tersebut muncul, terutama jika terdapat tuntutan pragmatisme dari instiusi media yang harus dipenuhi oleh seorang jurnalis. Wujudnya adalah motif kepentingan pada tingkat perorangan, diantaranya yang bersifat politis (partisan).

Motif tersebut menjadikan proses dan kerja berita bukan lagi didasarkan pada landasan etis dan profesional, namun pada landasan politik. Motif politik mampu menjadi ruh sekaligus menentukan arahnya sebuah laporan. Prosesnya berdasarkan kebijakan redaksional media yang menginginkan adanya sebuah frame yang didasarkan atas kepentingan internal media. Individu atau seorang jurnalis mengkonstruksi realitas sosial, dan merekonstruksikannya dalam dunia realitas, sekaligus memantapkan realitas itu berdasarkan kepentingan institusi medianya. (Eriyanto:2002).

Perlakukan yang berbeda-beda oleh kedua media yakni harian Radar Makassar dan Rakyat Sulsel terhadap keempat pasang calon tidak lain karena setiap koran memiliki pertimbanngan tersendiri dalam mengkontruksikan masing-masing kandidiat.(Hamad:2004).Inilah yang mejadi salah satu penyebab latar belakang munculnya berita-berita yang cenderung membela ataupun berpihak kepada salah satu paslon di Pilgub. Dari banyak berita yang disajikan oleh kedua media ini terkait empat pasangan peserta Pilgub Sulsel, bisa dibilang ruang NH-Aziz lebih bisa mendapatkan tempat. Di Raksul misalnya, beberapa berita yang tayang masih menunjukkan tren yang positif. Meskipun hanya di tempatkan pada halaman dalam. Sementara pada kondisi tertentu pula NH-Aziz harus legowo menerima bahwa ada "Tuang" yang mesti diutamakan yakni IYL-Cakka di harian Rakyat Sulsel. Mengingat IYL adalah salah satu pemilik saham dengan presentase 10 persen di Rakyat Sulsel.

Berdasarkan hasil analisis dengan menggunakan multi-level methods, ternyata dibalik realitas yang teramati(virtual reality)pada tataran deskripsi(analisis teks)tersimpan realitas yang tersembunyi(hidden 
reality)pada tataran interpretasi dan eksplanasi. Penggunaan paradigma kritikal dalam analisis wacana dapat membuat berita bercerita.Penggunaan metode yang bersifat saling menguatkan dapat mengungkap cerita di balik berita. Diantara cerita yang dapat terungkap di balik berita, adalah bahwa kedua media media ini memiliki orientasinya sendiri dalam berita-berita politik yang dibuatnya. Analisis pembingkaian teks-teks pada koran harian Radar Makassar dan Rakyat Sulsel di atas ditemukan fragmentasi wacana. Pembelahan berita yang terjadi dan tersaji di kedua media ini menunjukkan adanya keberpihakan media pada salah satu kandidat tertentu yang disalurkan oleh masing-masing aktor di redaksi yang terlibat dalam proses pemberitaan.Fragmentasi wacana yang terjadi juga menunjukkan bahwa kedua media ini tidak memiliki sikap yang tunggal atas satu persoalan.

Dari hasil penelitian ini menunjukkan bahwa antara pemberitaan mengenai empat paslon yang berlaga di Pilgub Sulsel, Radar Makasssar dan Rakyar Sulsel memiliki jagoan masing-masing. Hal ini menunjukkan bahwa wacana di harian Raksul dan Radar Makassarndipengaruhi oleh siapa wartawan yang menulisnya dan bagaimana sudut pandangnya. Padahal, sudut pandang (engle) seorang wartawan biasanya dipengaruhi oleh norma dan nilai yang dipegangnya atau oleh ideologi profesionalnya (Hall,1975; Fowler, 1991). Nilai dan ideologi yang dipegang wartawan ini akan dinegosiasikan dengan budaya tempat mereka bekerja dan juga oleh konteks ekonomi politik. Fragmentasi wacana ini menunjukkan bahwa masing-masing aktor atau wartawan di kedua media ini telah melakukan tafsir yang berbeda terhadap nilai budaya organisasi dan konteks ekonomi politik.

Sebagaimana disebutkan Shoemaker dan Reese (1996), pembingkaian suatu wacana di suatu media telah dimulai sejak dari proses pencarian fakta sosial, penentuan sumber berita, pengumpulan, penyortiran, dan penyeleksian, hingga akhirnya pemuatan berita sebagai realitas simbolik di media. Mengacu pada konsep Foucault bahwa kekuasan itu tidak lekat pada struktur tertentu, namun tersebar dan mewujud dalam setiap relasi sosial, maka kita bisa melihat praktik kuasa di balik kontestasi wacana pada kedua media tersebut dalam Pilgub Sulsel 2018 mulai dari level wartawan, redaktur hingga ke pimpinan di redaksi. Bisa dilihat bahwa munculnya berita-berita di harian Radar Makassar dan Rakyat Sulsel yang cenderung berpihak pada salah satu kandidat di Pilgub Sulsel hingga menyebabkan terjadinya pembelahan berita, tidak bisa dilepaskan dari kedekatan emosional wartawan hingga dijajaran redaksi terhadap kandidat. Itu diakui oleh sejumlah redaktur dan jajaran pimpinan di redaksi kedua media ini.

Permainan kuasa (power play) kemudian terjadi, yang melibatkan posisi masing-masing aktor dalam struktur redaksi baik harian Radar Makassar dan Rakyat Sulsel. Dimana selain karena para aktor wartawan dan redaktur di redaksi memiliki garapan iklan paslon, kedekatannya dengan sejumlah tokoh- 
tokoh yang ada di tim pemanangan ikut mempengaruhi kebijakan di meja redaksi. Itulah yang menyebabkan, berita terkait paslon di Pilgub Sulsel yang tayang di Raksul masih memiliki ruang, selain dari pada pengaruh iklan atau kerja sama yang menjadi prioritas. Permainan kuasa itu juga terjadi ketika si wartawan yang mengirim berita lantas resitensi terhadap kepentingan redaktur atau pimpinan redaksi, berita itu langsung dibatalkan.

Pada Pilgub Sulsel 2018, bisa dibaca bahwa beberapa redaktur di harian Raksul dan pimpinan redaksi di harian Radar Makassar telah menjadi rasa kecil yang dengan leluasa menyeleksi dan memilah berita yang diinginkan. Munculnya raja-raja kecil di jajaran redaksi kedua media tersebut menunjukkan bahwa dimensi ekonomi politik bukan faktor tunggal dalam mepengaruhi praktik pemberitaan mengenai kandidat kontestan Pilgub Sulsel. Fenomena ini sejalan dengan teori-teori diskursus dari Foucault dan relasi kuasanya yang menekankan pada pentingnya melihat relasi kuasa hingga level individual. Foucault memandang bahwa di mana saja ada atura dan manusia memiliki kohesi antara satu dan lainnnya dengan dunia, di tempat itulah kekuasaan bekerja. Persfektif ini tepat menggambarkan dialektika kekuasaan dan pengetahuan yang bekerja di harian Radar Makassar dan Rakyat Sulsel.

\subsection{Kekuatan Ekonomi di Balik Keterbelahan Berita}

Pada pembahasan sebelumnya menunjukkan adanya praktik swasensor yang dilakukan jajaran redaksi pada kedua media yang menjadi objek dalam penelitian ini. Di balik kontestasi wacana pro dan kontra terhadap kandidat tertentu di Pilgub Sulsel, sensor ini awalnya bersifat individu di ruang redaksi, namun kemudian didukung oleh para jajaran pemimpin koran ini. Sesuai konsep Shoemaker dan Reese (2014) dalam model yang disebutnya sebagai Hierarchical Influence Model, bias dalam praktik pemberitaan di suatu media yang dipengaruhi kepentingan personal dari individu wartawan, harus juga dilihat kaitannya dengan budaya organisasi di dalam media itu sendiri dan setting sosial dan ekonomi di belakangnya.

Dari aspek budaya organisasi, terlihat bahwa praktik swasensor ini telah menjadi habitus pada kedua media ini sejak lama. Sedangkan dengan melihat relasi bisnis antara masing-masing media dengan para kandidat di Pilgub Sulsel, kita bisa mengetahui bahwa upaya swasensor terhadap berita-berita pembelaan terhadap paslon tertentu atau pun berita yang cenderung negatif pada rival kandidat yang menjalin kerja sama ternyata juga memiliki dimensi eknomi politik yang kuat.

Bagi Radar Makassar dan Rakyat Sulsel, iklan merupakan bagian vital dalam menjalankan roda perusahaan karena merupakan bagian utama dari pendapatan. Harga jual koran tidak cukup untuk menutupi untuk biaya produksi. Sekalipun demikian, kita tidak bisa menarik kesimpulan begitu saja bahwa dengan adanya fakta pemberitaan yang cenderung memihak kepada salah satu kandidat yang memasang iklan dan menjadi sponsor kegiatan di kedua media ini, maka hal itu akan mempengaruhi 
pemberitaan di koran ini.

Baik harian Rakyat Sulsel maupun Radar Makassat memiliki kondisi yang sama terkait kekuatan ekonomi yang mempengaruhi setiap pemberitaan mengenai cagub di Pilgub Sulsel.Alur pemberitaan mengenai paslon di Pilgub Sulsel pada harian Radar Makassar seperti yang telah diulas pada laman sebelumnya, tidak bisa dilepaskan dari bagaimana kepentingan ekonomi perusahaan yang dititipkan melalui iklan dari para kandidat. Massifnya pemberitaan mengenai NH-Aziz pada periode Agustus hingga Desember 2017 misalnya, lalu kemudian tenggelam dan berita soal NH-Aziz sama sekali tidak pernah lagi muncul. Sementara pada periode yang sama, dukungan Radar Makassar justru beralih ke paslon lain yakni Agus-TBL.

Pada pembahasan sebelumnya telah diperlihatkan bahwa harian Raksul dan Radar Makassar mengkotruksikan secara berbeda-beda setiap paslon peserta Pilgub Sulsel 2018 dalam beritanya. Perlakukan yang berbeda itu tidak lain karena kedua media ini memiliki pertimbangan sendiri dalam mengkontruksi wacana yang disuguhkan kepada pembaca. Faktor kapital menjadi unsur yang esensial dalam sistem libertarian, hingga menciptakan fenomena konglomerasi media(Media Monopoly) proses kontruksi realitas pun diselaraskan dengan pertimbangan modal, baik yang langsung maupun tidak langsung berkaitan dengan usaha yang ada di bawah konglomerasi tersebut. Kontruksi realitas lazimnya dilakukan sedemikian rupa bilamana menyangkut kasus yang akan merugikan usaha atau relasi mereka.(Hamad. 2004).

Wujud lain dari faktor ekonomi, sebagai kekuatan eksternal lain yang berpengaruh atas penampilan isi media adalah khalayak dan pengiklan. Palaporan sebuah peristiwa, tidak terkecuali peristiwa politik, jelas harus memperhitungkan pasar. Semakin baik kualitas pelaporan (reportase), akan semakin banyak yang mengkonsumsi dan ini secara otomatis pengiklan pun cenderung akan bertambah. Hal ini ikut dipraktekkan oleh Raksul dan Radar Makassar. Sebagaimana yang dijelaskan Keller(2009) di media devisi iklan dan redaksi ditempatkan di bangunan yang berbeda, terpisah dan tidak pernah ketemu, demikian juga pimpinan redaksi. Keller juga menyebutkan bahwa wartawan-wartawan dilarang keras untuk melibatkan diri dalam pembuatan iklan. Namun demikian, situasi yang diamati Keller sudah berubah saat ini.

Memang benar, hingga saat ini devisi iklan dan redaksi masih ditempatkan dibangunan yang berbeda. Namun yang memisahkan iklan dan awak redaksi semakin padam. James Curran dalam Fuchs (2015), mengklasifikasikan kekuasaan media menjadi tiga kekuatan yakni kekuatan ekonomi, kekuasaan politik dalam media, dan kekuatan media dalam budaya. Curran menekankan bahwa kekuatan media tidak hanya simbolik, tetapi multidimensi. Kekuatan kuasa ekonomi media kata Curran 
tercermin dari konsetrrasi perusahaan di sektor pengiklanan demi memaksimalkan pendapatan. Tingginya biaya operasional media cetak, distribusi langganan koran tidak mampu menutupinya.

\section{REFERENCES}

Maryani Eni. 2010. Media dan Perubahan Sosial. Bandung. Rosda

Eriyanto. 2005, Analisis Wacana Pengantar Analisis Teks Media. Yogyakarta:

LKis.

Foucault, M. 2002. Pengetahuan dan Metode: Karya-karya Penting Foucault. Terjemahan dari P Rabinow, ed. Aesthetics, Method and Epistemology: Essential Works of Foucault 1954-1984. Yogyakarta: Jalasutra

Foucault, Michael. 2002. Power /Knowledge. Wacana Kuasa/Pengetahuan. Bentang Budaya, Jogjakarta.

Jorgensen, Marianne W dan Philips Louse J. Tanpa tahun. Analisis Wacana(Teori dan Metode).Terjemahan oleh Suyitno Imam dkk.2007. Yogyakarta : Pustaka Pelajar.

L.G. Seligman. Elite Recruitment and Political Development, Journal Of Politics, Agustus 1964.4 Cornelis Lay. Rekrutmen Elit Politik, Prisma No.4, April-Mei 1997, hal.21.

Hamad, Ibnu. 2004. Kontrusi Realitas Politik dalam Media Massa : Sebuah Studi Critical Discourse Analysis terhadap Berita-berita Politik. Jakarta. Granit.

Hermin Indah Wahyuni. Politik Media Dalam Transisi Politik: Dari Kontrol Negara Menuju SelfRegulation Mechanism. Jurnal Ilmu Komunikasi, Vol.4 Nomor 1, Juni 2007, hal. 15.

Istarno Rino.Kekuasaan Pemilik Modal Dalam Struktur Kapitalisme Media :Jurnal Lontar. Vol 4 Nomor 2. Mei 2016, Hal 15.

Jorgensen ,W Marianne dan J Lauise, Philips. 2007. Analisis Wacana (Teori dan Metode). Yogyakarta. Pustaka Pelajar.

Keller, Anett (2009). Tantangan dari Dalam: Otonomi redaksi di 4 Media Cetak Nasional: Kompas, Koran Tempo, Media Indonesia, dan Republika. Jakarta: Friderich Ebert Stiftung

Kusumaningrat, Hikma dan K. Purnama. 2012. Jurnalistik (Teori dan Praktik). Bandung. Remaja Rosdakarya.

Ritzer, George. Tanpa tahun. Teori Sosial Posmodern . Terjemahan oleh Muhammad Taufik. 2007. Yogyakarta . Kreasi Wacana.

Salim Agus. 2006. Teori dan Pradigma Penelitian Sosial. Yogyakarta. Tiara Wacana.

Sudibyo, A., \& Patria, N. (2013). "The Television Industry in Post Authoritarian Indoensia." Dalam Journal of Contemporary Asia, doi.10.1080/00472336.2012.757434

Sobur Alex. 2009 . Analisis Teks Media (Suatu Pengantar untuk Analisis Wacana, Analisis Simiotik, dan Analisis Framing). Bandung. Remaja Rosdakarya.

Undang-Undang Republik Indonesia No. 40 tahun 1999 tentang Pers. 